\title{
Production Performance and Milk Composition of Dairy Cows Fed Whole or Ground Flaxseed With or Without Monensin ${ }^{1,2}$
}

\author{
D. C. da Silva, ${ }^{\star}$ G. T. Santos, ${ }^{\star}$ A. F. Branco, ${ }^{\star}$ J. C. Damasceno, ${ }^{\star}$ R. Kazama, ${ }^{\star}$ M. Matsushita, $\dagger$ \\ J. A. Horst, $¥$ W. B. R. dos Santos, ${ }^{\star}$ and H. V. Petit $\S^{3}$ \\ *Departamento de Zootecnia, and \\ †Departamento de Química, Universidade Estadual de Maringá, Maringá, PR 87020-900, Brazil \\ ¥Associaçao Paranaense dos Criadores de Bovinos da Raça Holandesa Curitiba, PR 82800-000, Brazil \\ $\S$ Dairy and Swine Research and Development Centre, Agriculture and Agri-Food Canada, Succ Lennoxville, Sherbrooke, \\ QC J1M 1Z3, Canada
}

\begin{abstract}
Eight multiparous Holstein cows averaging $570 \pm 43$ $\mathrm{kg}$ of body weight and $60 \pm 20 \mathrm{~d}$ in milk were used in a double Latin square design with four 21-d experimental periods to determine the effects of feeding ground or whole flaxseed with or without monensin supplementation $(0.02 \%$ on a dry matter basis) on milk production and composition, feed intake, digestion, blood composition, and fatty acid profile of milk. Intake of dry matter was similar among treatments. Cows fed whole flaxseed had higher digestibility of acid detergent fiber but lower digestibilities of crude protein and ether extract than those fed ground flaxseed; monensin had no effect on digestibility. Milk production tended to be greater for cows fed ground flaxseed $(22.8 \mathrm{~kg} / \mathrm{d})$ compared with those fed whole flaxseed $(21.4 \mathrm{~kg} / \mathrm{d})$. Processing of flaxseed had no effect on $4 \%$ fat-corrected milk yield and milk protein and lactose concentrations. Monensin supplementation had no effect on milk production but decreased $4 \%$ fat-corrected milk yield as a result of a decrease in milk fat concentration. Feeding ground compared with whole flaxseed decreased concentrations of 16:0, 17:0, and cis6-20:4 and increased those of cis618:2, cis 9 , trans $11-18: 2$, and cis3-18:3 in milk fat. As a result, there was a decrease in concentrations of medium-chain and saturated fatty acids and a trend for higher concentrations of long-chain fatty acids in milk fat when feeding ground compared with whole flaxseed. Monensin supplementation increased concentrations of cis 9 and trans11-18:2 and decreased concentrations of saturated fatty acids in milk fat. There was an interac-
\end{abstract}

\footnotetext{
Received September 5, 2006.

Accepted February 13, 2007.

${ }^{1}$ The project was supported by the CNPq, Brasilia, DF, Processo No. 470378/2004-2, Universal.

${ }^{2}$ Contribution number 901 from the Dairy and Swine Research and Development Centre.

${ }^{3}$ Corresponding author: petith@agr.gc.ca
}

tion between flaxseed processing and monensin supplementation, with higher milk fat concentration of trans11-18:1 for cows fed ground flaxseed with monensin than for those fed the other diets. Flaxseed processing and monensin supplementation successfully modified the fatty acid composition of milk fat that might favor nutritional value for consumers.

Key words: dairy cow, flaxseed, protein, milk production

\section{INTRODUCTION}

Flaxseed is an excellent source of n-3 fatty acids (FA), which are reported to be anticarcinogenic, and which contribute to prevention of cardiovascular diseases and to improved vision (Wright et al., 1998). Infusion of flaxseed oil in the abomasum, which avoids ruminal biohydrogenation of polyunsaturated fatty acids (PUFA), increased milk concentration of linolenic acid to $13.9 \%$ of total FA as compared with $2.0 \%$ when whole flaxseed (WF) was fed in the diet of dairy cows (Petit et al., 2002). Therefore, methods to decrease ruminal biohydrogenation would increase the transfer of PUFA from flaxseed into milk. Experiments carried out with flaxseed used ground (Goodridge et al., 2001; Gonthier et al., 2004, 2005) or whole (Petit, 2002; Petit et al., 2002; Ward et al., 2002) seeds. No comparison has been found on the effect of grinding flaxseed, although processing would increase availability of oil in the rumen. As a result, greater biohydrogenation of flaxseed PUFA by rumen microbes may occur, thus increasing milk conjugated linoleic acid (CLA) concentration. Milk CLA is derived from rumen CLA and from endogenous synthesis of CLA in the mammary gland from cis9, trans1118:2 (Griinari et al., 2000).

Monensin (MO), which is an ionophore, has been used extensively in the diet of dairy cows, and effects on milk production and composition are well documented (Van der Werf et al., 1998; Phipps et al., 2000; Duffield et al., 2003). Monensin is also known to decrease in vitro 
ruminal biohydrogenation of PUFA (Van Nevel and Demeyer, 1995) and to increase in vitro total CLA concentration (Fellner et al., 1997), thus suggesting that dietary supplementation of MO could increase milk concentration of CLA and other PUFA. Concentrations of CLA, PUFA, and n-3 FA in milk after feeding MO could be greater with ground than WF due to a decrease in ruminal biohydrogenation of PUFA and a greater availability of oil in the rumen following grinding of flaxseed. Therefore, the objective of the present experiment was to determine the effects of feeding ground or WF with or without MO on feed intake, milk production, milk composition, milk FA profile, digestion, and blood composition of lactating dairy cows.

\section{MATERIALS AND METHODS}

\section{Animals and Diets}

A total of 8 multiparous Holstein cows averaging 570 $\pm 43 \mathrm{~kg}$ of BW and $60 \pm 20 \mathrm{DIM}$ were assigned to a replicated $4 \times 4$ Latin square design to determine the effects of flaxseed processing and MO supplementation on total tract apparent digestibility, feed intake, milk production, milk composition, and milk FA profile. Each experimental period consisted of $14 \mathrm{~d}$ of adaptation to the diets and $7 \mathrm{~d}$ for daily data collection of milk yield and feed intake. The 4 TMR (Table 1) consisted of supplements based on WF with no MO (CO), WF with $0.02 \% \mathrm{MO}$ on a DM basis, ground flaxseed (GF) with $\mathrm{CO}$, and GF with MO. Flaxseed was ground through a 10-mm screen using a Nogueira dpm-2 chopper (Irmãos Nogueira S.A. Máquinas Agrícolas e Motores, Itapira, São Paulo, Brazil).

Diets were formulated with similar chemical composition to meet nutrient requirements of a $570-\mathrm{kg}$ cow producing $25 \mathrm{~kg} / \mathrm{d}$ of milk containing $3.9 \%$ of fat (NRC, 2001). The experiment was conducted at the Iguatemi Experimental Farm, Maringa State University, Brazil. Cows were housed in tie stalls, fed individually, and milked twice daily at 0645 and $1530 \mathrm{~h}$. Milk production was recorded at each milking. Yield of FCM was calculated according to the equation of Tyrrell and Reid (1965). Cows were weighed on the first and last day of each experiment period.

\section{Sample Collection}

Feed consumption was recorded daily. Diets were fed twice daily at 0800 and $1600 \mathrm{~h}$ and adjusted for $100 \mathrm{~g}$ of orts $/ \mathrm{kg}$ as fed. Samples of each diet were collected daily from d 15 to 20 , frozen, and pooled on a period basis. Composite samples were mixed thoroughly and subsampled for chemical analyses. Samples of feces were collected for 6 consecutive days at $0800 \mathrm{~h}$ on d 15,
$1000 \mathrm{~h}$ on d $16,1200 \mathrm{~h}$ on d $17,1400 \mathrm{~h}$ on d 18,1600 $\mathrm{h}$ on d 19, and $1800 \mathrm{~h}$ on d 20 of each experimental period. Fecal samples were dried in a forced draft oven $\left(60^{\circ} \mathrm{C} ; 72 \mathrm{~h}\right.$ ), then ground through a 1-mm screen (Wiley mill model 4, Arthur H. Thomas, Philadelphia, PA). Equal DM from each fecal subsample was mixed to obtain a single composite for each sampled cow during each period. Milk samples were obtained from the 4 consecutive milkings on $\mathrm{d} 15$ and 16 of each experimental period and pooled within cow and period relative to production to obtain one composited milk sample per cow per period for chemical analysis. Milk samples were kept at room temperature with a preservative, 2-brome2-nitropropane-1,3 diol (Bronopol, D\&F Control Systems Inc., San Ramon, CA), for determination of protein, fat, and lactose concentrations. One sample without preservative was kept frozen to determine milk FA profile and MUN concentration. On d 18 of each experiment period, blood samples were withdrawn before the a.m. feeding from the jugular vein into Vacutainer tubes (Becton Dickinson and Cie, Rutherford, NJ) containing heparin for determination of total cholesterol, high-density lipoprotein (HDL) cholesterol, low-density lipoprotein (LDL) cholesterol, triglycerides, and glucose concentrations. The plasma was separated by centrifugation $(2,500 \times g$ for $20 \mathrm{~min})$.

\section{Chemical Analyses}

Dry matter of the diets was determined in a forced-air oven according to method 934.01 (AOAC, 1990). Total mixed diets were ground to pass a 1-mm screen in a Wiley mill before analyses of $\mathrm{N}$, ether extract, $\mathrm{ADF}$, and NDF. Total $\mathrm{N}$ determination used a Tecnal TE036/1 (Tecnal, Piracicaba, São Paulo, Brazil) following method 990.03 of AOAC (1990). Concentrations of NDF and ADF inclusive of residual ash were measured according to the nonsequential procedures of Van Soest et al. (1991) with the use of amylase but without sodium sulfite. Ether extraction in diets was conducted with Tecnal TE-044/1 according to the method no. 7.060 (AOAC, 1990). Period fecal, orts, and TMR composites were analyzed for indigestible NDF (the NDF remaining after $144 \mathrm{~h}$ of in vitro fermentation). Indigestible NDF was used as an internal marker to estimate apparent nutrient digestibility and fecal output (Cochran et al., 1986). Coefficients of apparent digestion of dietary components were determined by comparing dietary indigestible NDF concentration (corrected for orts) with fecal indigestible NDF concentration as outlined by Cochran et al. (1986). The N, fat, and lactose concentrations in milk were determined by infrared spectroscopy (Bentley model 2000; Bentley Instrument Inc., Chaska, MN). Concentration of MUN was deter- 
Table 1. Chemical composition of total mixed diets of Holstein cows fed whole flaxseed without monensin (WFCO), whole flaxseed with monensin (WFMO), ground flaxseed without monensin (GFCO), or ground flaxseed with monensin (GFMO)

\begin{tabular}{|c|c|c|c|c|c|c|c|c|}
\hline \multirow[b]{3}{*}{ Item } & \multirow{2}{*}{\multicolumn{4}{|c|}{ Treatment }} & \multirow[b]{3}{*}{$\mathrm{SE}$} & \multicolumn{3}{|c|}{$P$-value } \\
\hline & & & & & & & & Flaxseed \\
\hline & WFCO & WFMO & GFCO & GFMO & & Flaxseed & Monensin & $\times$ monensin \\
\hline \multicolumn{9}{|l|}{ Ingredient, \% of DM } \\
\hline Corn silage & 60.0 & 60.0 & 60.0 & 60.0 & & & & \\
\hline Ground corn & 8.8 & 8.8 & 8.8 & 8.8 & & & & \\
\hline Soybean meal & 17.7 & 17.7 & 17.7 & 17.7 & & & & \\
\hline Whole flaxseed & 12.0 & 12.0 & 0 & 0 & & & & \\
\hline Ground flaxseed & 0 & 0 & 12.0 & 12.0 & & & & \\
\hline \multicolumn{9}{|l|}{ Mineral and vitamin } \\
\hline Supplement ${ }^{1}$ & 1.50 & 1.48 & 1.50 & 1.48 & & & & \\
\hline Monensin & 0 & 0.02 & 0 & 0.02 & & & & \\
\hline \multicolumn{9}{|l|}{ Chemical analysis } \\
\hline $\mathrm{DM}, \%$ & 54.0 & 54.0 & 53.9 & 53.9 & 0.1 & 0.15 & 0.57 & 1.0 \\
\hline $\mathrm{CP}, \%$ of $\mathrm{DM}$ & 16.4 & 16.5 & 16.4 & 16.5 & 0.1 & 0.87 & 0.05 & 1.0 \\
\hline Ether extract, \% of DM & 6.4 & 6.4 & 6.4 & 6.4 & 0.1 & 0.51 & 0.49 & 1.0 \\
\hline $\mathrm{NDF}, \%$ of $\mathrm{DM}$ & 40.4 & 40.0 & 40.4 & 40.0 & 0.3 & 0.98 & 0.13 & 1.0 \\
\hline $\mathrm{ADF}, \%$ of $\mathrm{DM}$ & 23.5 & 23.6 & 23.4 & 23.6 & 0.04 & 0.51 & 0.001 & 1.0 \\
\hline $\mathrm{NE}_{\mathrm{L}},{ }^{2} \mathrm{Mcal} / \mathrm{kg}$ & 1.44 & 1.45 & 1.47 & 1.49 & & & & \\
\hline $\mathrm{NSC}^{2} \%$ of DM & 30.3 & 31.1 & 30.4 & 31.2 & & & & \\
\hline \multicolumn{9}{|l|}{ Fatty acid, ${ }^{3} \%$ of total } \\
\hline $\mathrm{C} 16: 0$ & 15.7 & 15.5 & 15.8 & 15.6 & 0.2 & 0.69 & 0.19 & 1.0 \\
\hline C18:0 & 4.4 & 4.4 & 4.6 & 4.6 & 0.1 & 0.05 & 0.70 & 1.0 \\
\hline C18:1 & 28.6 & 28.9 & 29.0 & 29.3 & 0.4 & 0.40 & 0.20 & 1.0 \\
\hline C18:2 & 36.1 & 35.8 & 36.1 & 35.9 & 0.2 & 0.96 & 0.20 & 1.0 \\
\hline C18:3 & 10.2 & 10.2 & 9.5 & 9.4 & 0.2 & 0.003 & 0.77 & 1.0 \\
\hline Others & 5.0 & 5.2 & 5.0 & 5.2 & 0.1 & 0.84 & 0.14 & 1.0 \\
\hline
\end{tabular}

${ }^{1}$ Contained $27.0 \% \mathrm{Ca}, 8.0 \% \mathrm{P}, 2.0 \% \mathrm{Mg}, 2.0 \% \mathrm{~S}, 2,200 \mathrm{mg} / \mathrm{kg}$ of Fe, 2,800 mg/kg of Zn, $800 \mathrm{mg} / \mathrm{kg} \mathrm{of} \mathrm{Cu}$, $801 \mathrm{mg} / \mathrm{kg}$ of F, $60 \mathrm{mg} / \mathrm{kg}$ of I, $50 \mathrm{mg} / \mathrm{kg}$ of Co, $40 \mathrm{mg} / \mathrm{kg}$ of Se, $216,000 \mathrm{IU} / \mathrm{kg}$ of vitamin A, 67,600 UI/kg of vitamin $\mathrm{D}_{3}$, and $500 \mathrm{IU} / \mathrm{kg}$ of vitamin $\mathrm{E}$.

${ }^{2}$ Calculated using published values of feed ingredients (NRC, 2001).

${ }^{3}$ Mean of 7 daily samples collected and accumulated during the digestibility trial.

mined according to the method of Marsh et al. (1965). Milk SCC were obtained using an electronic counter (Somacount 500, Chaska, MN) as described by Voltolini et al. (2001).

Fat in milk was separated by centrifugation as described by Murphy et al. (1995), and FA were methylated according to method 5509 of ISO (1978) using KOH/methanol (Synth, São Paulo, Brazil) and n-heptane (Vetec, Rio de Janeiro, Brazil). Fatty acid methyl ester profiles were measured at a split ratio of 1:80 by GLC on a Varian chromatograph (Palo Alto, CA) with a G1315A autosampler equipped with a flame-ionization detector and a CP-7420 fused silica capillary column ( $100 \mathrm{~m}$ and $0.25 \mathrm{~mm}$ i.d., $0.25-\mu \mathrm{m}$ film thickness). The column parameters were as follows: initial column temperature of $65^{\circ} \mathrm{C}$ was maintained for $8 \mathrm{~min}$; the temperature was then programmed at $50^{\circ} \mathrm{C}$ per min to $170^{\circ} \mathrm{C}$. This temperature was maintained for $40 \mathrm{~min}$, then increased $50^{\circ} \mathrm{C}$ per min to $240^{\circ} \mathrm{C}$, and remained at this temperature for $28.5 \mathrm{~min}$. Injector and detector temperatures were 220 and $245^{\circ} \mathrm{C}$, respectively. The carrier gas was hydrogen at $1.4 \mathrm{~mL} / \mathrm{min}$. Hydrogen flow to the detector was $30 \mathrm{~mL} / \mathrm{min}$, airflow was $300 \mathrm{~mL} / \mathrm{min}$, and the flow of $\mathrm{N}_{2}$ make-up gas was $30 \mathrm{~mL} / \mathrm{min}$. Fatty acid peaks were identified using pure methyl ester standards (Sigma, São Paulo, Brazil).

Plasma triglycerides (Triglycerides FS, DiaSys, Holzheim, Germany), HDL cholesterol (HDL-C Immuno FS, DiaSys), LDL cholesterol (LDL-C Select FS, DiaSys), total cholesterol (Cholesterol FS, DiaSys), and glucose (Glucose GOD FS, DiaSys) concentrations were analyzed by colorimetric methods.

\section{Statistical Analysis}

All results were analyzed using the MIXED procedure of SAS (2000) within a $2 \times 2$ factorial arrangement of treatments. Data on digestion, milk production, milk composition, blood composition, and feed intake were analyzed using a replicated $4 \times 4$ Latin square design with the following general model:

$$
\mathrm{Y}_{\mathrm{ijk} \mathrm{k}}=\mu+\mathrm{S}_{\mathrm{i}}+\mathrm{C}_{\mathrm{j}(\mathrm{i})}+\mathrm{P}_{\mathrm{k}}+\mathrm{T}_{\mathrm{l}}+\mathrm{e}_{\mathrm{ijk} \mathrm{k}}
$$

where $Y_{\mathrm{ijkl}}=$ the dependent variable, $\mu$ = overall mean, $\mathrm{S}_{\mathrm{i}}=$ random effect of square ( $\mathrm{i}=1$ to 2$), \mathrm{C}_{\mathrm{j}(\mathrm{i})}=$ random 
Table 2. Feed intake, milk production, and milk composition of Holstein cows fed whole flaxseed without monensin (WFCO), whole flaxseed with monensin (WFMO), ground flaxseed without monensin (GFCO), or ground flaxseed with monensin $(\mathrm{GFMO})^{1}$

\begin{tabular}{|c|c|c|c|c|c|c|c|c|}
\hline \multirow[b]{3}{*}{ Item } & \multirow{2}{*}{\multicolumn{4}{|c|}{ Treatment }} & \multirow[b]{3}{*}{$\mathrm{SE}$} & \multicolumn{3}{|c|}{$P$-value } \\
\hline & & & & & & & & Flaxseed \\
\hline & WFCO & WFMO & GFCO & GFMO & & Flaxseed & Monensin & $\times$ monensin \\
\hline DMI, kg/d & 16.1 & 16.0 & 16.4 & 16.1 & 0.2 & 0.31 & 0.43 & 0.61 \\
\hline DMI, \% of BW & 2.91 & 2.78 & 2.88 & 2.80 & 0.06 & 0.95 & 0.12 & 0.66 \\
\hline $\mathrm{CP}$ intake, $\mathrm{kg} / \mathrm{d}$ & 2.70 & 2.70 & 2.76 & 2.73 & 0.03 & 0.28 & 0.72 & 0.67 \\
\hline Milk production, $\mathrm{kg} / \mathrm{d}$ & 21.3 & 21.5 & 22.8 & 22.7 & 0.7 & 0.07 & 0.98 & 0.82 \\
\hline $4 \%$ FCM, kg/d & 22.7 & 20.8 & 22.5 & 21.9 & 0.6 & 0.47 & 0.05 & 0.31 \\
\hline \multicolumn{9}{|l|}{ Milk composition, \% } \\
\hline Protein & 3.13 & 3.10 & 3.11 & 3.10 & 0.05 & 0.91 & 0.77 & 0.91 \\
\hline Fat & 4.44 & 3.81 & 3.90 & 3.75 & 0.18 & 0.11 & 0.04 & 0.21 \\
\hline Lactose & 4.57 & 4.62 & 4.61 & 4.66 & 0.03 & 0.15 & 0.10 & 0.88 \\
\hline Urea N & 16.9 & 17.1 & 18.8 & 18.5 & 0.7 & 0.03 & 0.92 & 0.77 \\
\hline Total solids & 13.4 & 12.6 & 12.7 & 12.5 & 0.1 & 0.04 & 0.009 & 0.07 \\
\hline $\mathrm{SCC}, \times 10^{3} / \mathrm{mL}$ & 2.46 & 2.42 & 2.56 & 2.34 & 0.13 & 0.91 & 0.33 & 0.49 \\
\hline $\mathrm{SCS}^{2}$ & 540.8 & 779.9 & 573.6 & 396.7 & 253.8 & 0.49 & 0.90 & 0.42 \\
\hline \multicolumn{9}{|l|}{ Milk yield, $\mathrm{kg} / \mathrm{d}$} \\
\hline Protein & 0.66 & 0.65 & 0.69 & 0.69 & 0.02 & 0.21 & 0.80 & 0.87 \\
\hline Fat & 0.95 & 0.82 & 0.89 & 0.86 & 0.03 & 0.84 & 0.02 & 0.17 \\
\hline
\end{tabular}

${ }^{1}$ Least squares means with pooled SE.

${ }^{2} \mathrm{SCS}=\log _{10} \mathrm{SCC}$.

effect of cow within square $(\mathrm{j}=1$ to 4$), \mathrm{P}_{\mathrm{k}}=$ fixed effect of period ( $\mathrm{k}=1$ to 4$), \mathrm{T}_{1}$ = fixed effect of treatment $(\mathrm{l}=\mathrm{WFCO}, \mathrm{WFMO}, \mathrm{GFCO}, \mathrm{GFMO})$, and $\mathrm{e}_{\mathrm{ijkl}}=$ random residual error. Treatments were compared with provide factorial contrasts: 1) WF vs. GF, 2) with vs. without monensin, and 3) the interaction between flaxseed processing and monensin supplementation. Significance was declared at $P<0.05$ and a trend at $0.5<P<0.10$, unless otherwise stated.

\section{RESULTS AND DISCUSSION}

The chemical composition of the TMR (Table 1) was generally similar among diets. Ground flaxseed had higher and lower percentage of 18:0 and 18:3 FA, respectively, than WF, which may suggest partial modification of long-chain FA during processing of the seeds. Similarly, Gonthier et al. (2004) reported that extruded and micronized flaxseed had lower concentration of 18:3 and higher concentration of 18:0 than raw flaxseed. There was no significant interaction between flaxseed processing and monensin supplementation for DMI, CP intake, milk production, 4\% FCM yield, milk composition, and milk yield of components (Table 2). Intake of DM, expressed as kilograms per day or as a percentage of BW, was similar among treatments. Monensin was fed at $0.02 \%$ of the DM and DMI of cows fed MO averaged $16.1 \mathrm{~kg} / \mathrm{d}$, thus resulting in an average intake of $320 \mathrm{mg}$ of monensin per d. Similarly, feeding monensin at $22 \mathrm{mg} / \mathrm{kg}$ of DM (Plaizier et al., 2000; Osborne et al., 2004), $24 \mathrm{mg} / \mathrm{kg}$ of DM (Bell et al., 2006), or $300 \mathrm{mg} / \mathrm{d}$
(Van Der Werf et al., 1998; Phipps et al., 2000) had no effect on DMI of dairy cows. Moreover, cows fed ground (Ward et al., 2002; Gonthier et al., 2005) or whole (Kennelly, 1996; Petit et al., 2004) flaxseed had similar DMI compared with those fed no flaxseed, thus suggesting that grinding of flaxseed does not affect DMI.

Intake of $\mathrm{CP}$, expressed as kilograms per day, was similar among treatments as a result of similar DMI. Milk production tended $(P=0.07)$ to be $6.5 \%$ greater $(+1.4 \mathrm{~kg} / \mathrm{d})$ for cows fed GF compared with those fed WF. Similarly, Kennelly (1996) reported higher milk production $(+2.0 \mathrm{~kg} / \mathrm{d})$ for cows fed rolled flaxseed compared with those fed WF. Processing of flaxseed had no effect on 4\% FCM yield. Milk protein and lactose concentrations were similar for cows fed WF and GF. Milk fat concentration tended $(P=0.11)$ to decrease with flaxseed processing, which may indicate a greater release of oil in the rumen (Mohamed et al., 1988) due to grinding. Milk urea $\mathrm{N}$ concentration was higher for cows fed GF compared with WF. Physical breakdown of seeds is known to increase ruminal CP degradability (Stern et al., 1994). Therefore, greater ruminal CP degradability for GF rather than WF may contribute to increase urea $\mathrm{N}$ concentration in milk; DePeters and Cant (1992) reported that feeding high compared with low ruminal degradable protein increases $(P=0.08)$ milk NPN concentration. The greater oil release with ground rather than WF could also contribute to affect milk urea $\mathrm{N}$ concentration, although the effects of feeding protected and unprotected fat supplements on milk urea $\mathrm{N}$ concentrations are still unclear (DePeters and 
Cant, 1992). Feeding WF compared with GF increased concentration of milk total solids but the increase was more important when cows were fed no monensin, which tended $(P=0.07)$ to result in an interaction between flaxseed processing and monensin supplementation. Somatic cell count and SCS were not affected by flaxseed processing. Milk yields of protein and fat were similar for cows fed WF and GF.

Monensin supplementation had no effect on milk production. This disagrees with earlier trials establishing that the inclusion of $300 \mathrm{mg}$ of monensin/d in dairy cow diets for the first $25 \mathrm{wk}$ of lactation would increase milk yield (Van der Werf et al., 1998; Phipps et al., 2000). However, feeding monensin at 24 and $22 \mathrm{mg} / \mathrm{kg}$ of DM, respectively, for 15- (Bell et al., 2006) and 35-d (Osborne et al., 2004) periods had no effect on DMI and milk yield of dairy cows. Discrepancies between studies could be related to factors such as stage of lactation, diet composition, and length of the trial. Moreover, Sauer et al. (1998) suggested that some adaptive changes occur in the rumen microflora following monensin supplementation and cows that had previously received monensin no longer respond. The response to monensin regarding milk production and composition also differs with genetic line, cows with the highest capacity of milk production responding best to monensin supplementation (Van der Werf et al., 1998). The lack of any effect on milk production in the present experiment where cows averaged $20 \mathrm{~kg} / \mathrm{d}$ would corroborate this finding.

Cows fed monensin had lower 4\% FCM yield as a result of the decrease in milk fat concentration. This agrees with the well-documented decrease in milk fat concentration reported when adding monensin to a dairy cow diet (Sauer et al., 1998; Dhiman et al., 1999; Phipps et al., 2000; Bell et al., 2006) due to the reduction of molar proportions of acetate and butyrate and the increase of propionate (Sauer et al., 1998). Moreover, monensin supplementation reduced milk fat percentage in cows receiving diets with less than $40 \%$ NSC (Duffield et al., 2003), which is in the range of values observed for the present experiment (Table 1). Milk lactose concentration tended $(P=0.10)$ to be higher with than without MO supplementation. Feeding monensin had no effect on milk protein and MUN concentrations, SCC, SCS, and milk yield of protein. In general, milk protein concentration is little affected by monensin supplementation (Sauer et al., 1998; Ruiz et al., 2001; Bell et al., 2006), although it decreased (Phipps et al., 2000) or increased (Duffield et al., 1998, 2003) in some cases.

In general, there were no interactions between flaxseed processing and monensin supplementation on milk concentrations of individual FA with the exception of trans11-18:1 (Table 3). Feeding ground compared with WF decreased concentrations of cis10-15:1, 16:0, 17:0, and cis6-20:4, and it increased those of cis6-18:2, cis9, trans11-18:2, cis3-18:3, and n-3 FA. Moreover, flaxseed processing tended $(P<0.10)$ to decrease concentrations of cis7-16:1 and n-6 and to increase those of cis3-20:5 and unidentified FA. As a result, there was a decrease in concentrations of medium-chain and saturated FA and a trend for higher $(P=0.06)$ concentrations of longchain FA following grinding of flaxseed. Similar differences in concentrations of milk FA were generally observed when rolled flaxseed was compared with WF (Kennelly, 1996). Physical breakdown of flaxseed may contribute to increase availability of FA for absorption and transfer in milk partly as a result of more rapid passage rate out of the rumen with ground than WF, which would increase concentrations of linolenic acid and n-3 FA in milk. Moreover, grinding of flaxseed may also increase partial ruminal biohydrogenation of C18:3 as shown by the greater cis9, trans 11-18:2 concentration in milk fat of cows fed ground compared with WF. Long-chain PUFA (18:2 and 18:3) are subjected to biohydrogenation processes in the rumen, and the intermediate steps for converting C18:2 to CLA have been suggested by Kepler and Tove (1967). Other results (Dhiman et al., 1999) suggest that C18:3 might be also a substrate for conversion to CLA in the rumen. Although the C18:3 FA can be biohydrogenated in the rumen, they do not appear to increase the secretion of CLA into milk, as is the case with C18:2 FA (Lock and Garnsworthy, 2002). It is believed that the C18:3 FA might limit the formation of the trans11-18:1, which is converted to CLA in the mammary gland (Griinari and Bauman, 1999). On the other hand, Chilliard et al. (2000) reported that flaxseed oil greatly increases milk fat CLA content and is at least as efficient as C18:2-rich vegetable oils, thus suggesting that feeding flaxseed oil results in a large increase in the production of ruminal trans 11 $18: 1$, which can be used by the mammary gland for CLA synthesis. In the present experiment, cows fed the GFMO diet had the highest trans11-18:1 concentration and the trend for the highest $(P=0.11)$ CLA concentration, thus suggesting that C18:3 does not always interfere with the conversion of CLA in the mammary gland.

Monensin supplementation decreased concentrations of cis6-20:4, cis6-22:4 and increased those of cis9, trans11-18:2, trans10-18:2, and unidentified FA. Supplementation with monensin tended $(P<0.10)$ to increase concentrations of $17: 0$, iso $17: 0$, cis $6-18: 2$, and $\mathrm{n}-6$ and to decrease concentrations of cis3-22:6, thus resulting in lower concentrations of saturated FA for cows fed MO compared with those fed no MO. Similarly, Sauer et al. (1998) reported an increase in trans11-18:1 and C18:2 FA with monensin supplementation. There was an interaction between flaxseed processing and 
Table 3. Fatty acid concentrations in milk of Holstein cows (percentage of total fatty acids) fed whole flaxseed without monensin (WFCO), whole flaxseed with monensin (WFMO), ground flaxseed without monen$\sin (\mathrm{GFCO})$, or ground flaxseed with monensin $(\mathrm{GFMO})^{1}$

\begin{tabular}{|c|c|c|c|c|c|c|c|c|}
\hline \multirow[b]{3}{*}{ Item $^{2}$} & \multirow{2}{*}{\multicolumn{4}{|c|}{ Treatment }} & \multirow[b]{3}{*}{$\mathrm{SE}$} & \multicolumn{3}{|c|}{$P$-value } \\
\hline & & & & & & & & Flaxseed \\
\hline & WFCO & WFMO & GFCO & GFMO & & Flaxseed & Monensin & $\times$ monensin \\
\hline $6: 0$ & 0.45 & 0.40 & 0.43 & 0.41 & 0.09 & 0.95 & 0.72 & 0.85 \\
\hline $8: 0$ & 0.52 & 0.45 & 0.48 & 0.44 & 0.08 & 0.77 & 0.52 & 0.87 \\
\hline $10: 0$ & 1.72 & 1.52 & 1.60 & 1.43 & 0.18 & 0.58 & 0.33 & 0.93 \\
\hline 11:0 & 0.04 & 0.04 & 0.04 & 0.03 & 0.01 & 0.32 & 0.83 & 0.33 \\
\hline 12:0 & 2.17 & 2.03 & 2.06 & 1.90 & 0.16 & 0.46 & 0.37 & 0.95 \\
\hline $13: 0$ & 0.07 & 0.09 & 0.08 & 0.07 & 0.01 & 0.47 & 0.51 & 0.29 \\
\hline 14:0 & 9.18 & 8.96 & 8.93 & 8.32 & 0.38 & 0.26 & 0.28 & 0.60 \\
\hline cis 10-15:1 & 0.83 & 0.93 & 0.79 & 0.79 & 0.04 & 0.05 & 0.26 & 0.23 \\
\hline $16: 0$ & 26.38 & 26.43 & 24.62 & 23.27 & 0.64 & 0.001 & 0.32 & 0.28 \\
\hline iso16:0 & 0.22 & 0.20 & 0.19 & 0.20 & 0.02 & 0.41 & 0.79 & 0.42 \\
\hline cis $9-16: 1$ & 0.32 & 0.31 & 0.30 & 0.31 & 0.03 & 0.69 & 0.85 & 0.71 \\
\hline cis $7-16: 1$ & 1.36 & 1.34 & 1.16 & 1.24 & 0.11 & 0.07 & 0.71 & 0.52 \\
\hline $17: 0$ & 0.49 & 0.53 & 0.47 & 0.48 & 0.01 & 0.01 & 0.06 & 0.40 \\
\hline iso17:0 & 0.57 & 0.60 & 0.50 & 0.58 & 0.02 & 0.11 & 0.07 & 0.39 \\
\hline cis10-17:1 & 0.23 & 0.22 & 0.18 & 0.24 & 0.03 & 0.70 & 0.45 & 0.34 \\
\hline $18: 0$ & 17.34 & 17.36 & 18.84 & 16.76 & 0.73 & 0.54 & 0.17 & 0.16 \\
\hline trans11-18:1 & 1.40 & 1.59 & 1.71 & 3.33 & 0.06 & 0.0001 & 0.0001 & 0.0001 \\
\hline cis9-18:1 & 29.08 & 28.37 & 29.01 & 29.30 & 0.85 & 0.61 & 0.80 & 0.56 \\
\hline cis $6-18: 2$ & 1.70 & 1.90 & 1.91 & 2.09 & 0.10 & 0.04 & 0.05 & 0.93 \\
\hline cis 9 ,trans $11-18: 2$ & 0.47 & 0.55 & 0.56 & 1.01 & 0.11 & 0.02 & 0.02 & 0.11 \\
\hline trans 10-18:2 & 0.06 & 0.06 & 0.05 & 0.07 & 0.01 & 0.40 & 0.02 & 0.17 \\
\hline cis3-18:3 & 0.66 & 0.67 & 1.05 & 0.80 & 0.07 & 0.004 & 0.14 & 0.12 \\
\hline cis6-20:4 & 0.13 & 0.11 & 0.11 & 0.10 & 0.01 & 0.03 & 0.02 & 0.94 \\
\hline cis $3-20: 5$ & 0.05 & 0.05 & 0.07 & 0.06 & 0.01 & 0.07 & 0.14 & 0.56 \\
\hline cis6-22:4 & 0.03 & 0.02 & 0.03 & 0.02 & 0.01 & 0.24 & 0.02 & 0.29 \\
\hline cis3-22:6 & 0.08 & 0.08 & 0.09 & 0.08 & 0.01 & 0.50 & 0.06 & 0.48 \\
\hline Total trans & 1.93 & 2.20 & 2.32 & 4.40 & 0.15 & 0.01 & 0.01 & 0.01 \\
\hline Unidentified & 4.47 & 5.19 & 4.75 & 6.66 & 0.44 & 0.06 & 0.007 & 0.18 \\
\hline MUFA & 33.2 & 32.8 & 33.2 & 35.2 & 0.9 & 0.19 & 0.37 & 0.17 \\
\hline PUFA & 3.1 & 3.4 & 3.9 & 4.2 & 0.2 & 0.001 & 0.11 & 0.82 \\
\hline SFA & 59.1 & 58.6 & 58.2 & 53.9 & 1.1 & 0.02 & 0.04 & 0.10 \\
\hline PUFA/SFA & 0.053 & 0.061 & 0.067 & 0.080 & 0.004 & 0.002 & 0.04 & 0.56 \\
\hline SCFA & 5.0 & 4.5 & 4.7 & 4.3 & 0.5 & 0.61 & 0.44 & 0.96 \\
\hline MCFA & 36.6 & 36.5 & 34.5 & 32.6 & 0.8 & 0.003 & 0.25 & 0.29 \\
\hline LCFA & 53.9 & 53.7 & 56.0 & 56.4 & 1.2 & 0.06 & 0.92 & 0.80 \\
\hline$n-3^{3}$ & 0.80 & 0.79 & 1.20 & 0.94 & 0.1 & 0.003 & 0.10 & 0.11 \\
\hline$n-6^{4}$ & 1.84 & 2.03 & 2.04 & 2.20 & 0.1 & 0.07 & 0.09 & 0.92 \\
\hline$n-6: n-3$ & 2.4 & 2.7 & 1.8 & 2.4 & 0.1 & 0.007 & 0.008 & 0.37 \\
\hline
\end{tabular}

${ }^{1}$ Least squares means with pooled SE.

${ }^{2}$ MUFA = monounsaturated fatty acids; PUFA = polyunsaturated fatty acids; SFA = saturated fatty acids; SCFA = short-chain fatty acids; MCFA = medium-chain fatty acids; LCFA = long-chain fatty acids.

${ }^{3}$ Cis3-18:3 + cis3-20:5 + cis3-22:6.

${ }^{4}$ Cis6-18:2 + cis6-20:4 + cis6-22:4.

monensin supplementation as a result of higher concentration of trans11-18:1 and total trans FA in milk fat of cows fed GF with monensin than in milk fat of those fed the other diets. In parallel, highest $(P=0.11)$ numerical concentrations of cis 9, trans11-18:2 and a trend $(P=0.10)$ for lower concentration of saturated FA in milk fat were observed for cows fed GF with monensin compared with those fed the other 3 diets. It was suggested that MO can modify milk FA profile by inhibiting biohydrogenation of linoleic acid (C18:2) and increasing the content of C18:1 (Fellner et al., 1997; Sauer et al., 1998). Moreover, higher concentrations of linoleic acid (C18:2), trans11-18:1, and CLA in continuous cultures of ruminal bacteria following infusion of monensin were reported by Fellner et al. (1997). Therefore, this would suggest that monensin supplementation was successful in decreasing complete ruminal biohydrogenation of FA of $\mathrm{GF}$ as indicated by the trend $(P=0.10)$ for lower concentrations of saturated FA in milk fat and by the highest concentration of trans 11-18:1 and the trend $(P=$ 0.11 ) for the highest concentration of $c i s 9$, trans 11-18:2 in milk fat.

The n-6 to n-3 FA ratio in milk fat was significantly lower for cows fed ground compared with WF and cows fed no monensin had a lower ratio than those fed monensin. The $n-6$ to $n-3$ FA ratios were within the range 
Table 4. Digestion of Holstein cows fed whole flaxseed without monensin (WFCO), whole flaxseed with monensin (WFMO), ground flaxseed without monensin (GFCO), or ground flaxseed with monensin $(\mathrm{GFMO})^{1}$

\begin{tabular}{|c|c|c|c|c|c|c|c|c|}
\hline \multirow[b]{3}{*}{ Item } & \multirow{2}{*}{\multicolumn{4}{|c|}{ Treatment }} & \multirow[b]{3}{*}{ SE } & \multicolumn{3}{|c|}{$P$-value } \\
\hline & & & & & & & & Flaxseed \\
\hline & WFCO & WFMO & GFCO & GFMO & & Flaxseed & Monensin & $\times$ monensin \\
\hline \multicolumn{9}{|l|}{ Digestibility, \% } \\
\hline DM & 58.6 & 59.7 & 58.7 & 59.6 & 0.7 & 0.99 & 0.19 & 0.87 \\
\hline $\mathrm{ADF}$ & 36.3 & 36.4 & 31.5 & 34.6 & 1.5 & 0.04 & 0.29 & 0.34 \\
\hline $\mathrm{NDF}$ & 38.7 & 39.8 & 37.4 & 37.5 & 1.3 & 0.18 & 0.66 & 0.70 \\
\hline $\mathrm{CP}$ & 65.9 & 67.9 & 69.4 & 69.3 & 1.6 & 0.003 & 0.20 & 0.16 \\
\hline Ether extract & 73.1 & 73.6 & 87.4 & 89.3 & 3.4 & 0.0001 & 0.34 & 0.55 \\
\hline $\mathrm{OM}$ & 49.8 & 49.6 & 51.3 & 50.8 & 0.7 & 0.07 & 0.61 & 0.81 \\
\hline
\end{tabular}

${ }^{1}$ Least squares means with pooled SE.

usually reported when feeding flaxseed (Petit, 2002; Petit et al., 2002).

There was no interaction between flaxseed processing and monensin supplementation for digestibility (Table 4). Cows fed WF had higher digestibilities of ADF but lower digestibilities of $\mathrm{CP}$ and ether extract than those fed GF. Lower fiber digestibility is associated with process such as grinding (Scott et al., 1991) and is consistent with the release of oil from the seed into the rumen (Murphy et al., 1990). That cows fed GF had higher milk CLA concentration than those fed WF agrees with a higher release of oil in the rumen and ruminal biohydrogenation of PUFA and the decrease in fiber digestibility observed with feeding of GF. On the other hand, grinding could contribute to increase digestibility of fat by releasing a greater amount of oil in the rumen and the intestine as discussed previously. Rumen protection of CP usually parallels fat as a protein-rich matrix surrounds the fat droplets of oilseeds (Khorasani et al., 1992); therefore, greater availability of protein will parallel that of oil, thus increasing digestibility of fat and protein as observed in the present experiment. There was a trend $(P=0.07)$ for flaxseed processing to increase digestibility of OM.

Monensin supplementation had no effect on digestibilities of DM, ADF, NDF, CP, ether extract, and OM. Similar results have been reported by Benchaar et al. (2006) and Plaizier et al. (2000), although monensin increased CP digestibility in both studies. Discrepancies between studies could partly be due to differences in diet composition. According to Plaizier et al. (2000), MO supplementation increases CP digestibility in cows fed high concentrate diets, whereas it has no effect in those fed high forage diets. Diets used in the experiments of Benchaar et al. (2006) and Plaizier et al. (2000) contained, respectively, 52.0 and $57.4 \%$ concentrate, and MO supplementation increased CP digestibility. On the other hand, diets used by Haimoud et al. (1995) and in the present experiment contained, respectively,
35.4 and $40.0 \%$ concentrate, and MO had no effect on CP digestibility, which would corroborate that hypothesis.

Flaxseed processing had no effect on plasma concentrations of glucose, triglycerides, total cholesterol, HDL, and LDL cholesterol (Table 5). Similar plasma concentrations of total cholesterol, HDL and LDL cholesterol, and glucose have been reported when feeding calcium salts of palm oil, micronized soybeans, or WF (Petit et al., 2004). Plasma concentration of glucose tended $(P=$ 0.09 ) to be higher for cows fed monensin than for those fed no monensin as previously reported by Duffield et al. (1998), although others found no difference (Abe et al., 1994; Sauer et al., 1998). According to Duffield et al. (1998), monensin supplementation has positive effects on energy indicators and blood concentration of glucose mediated through different ways such as increased propionate concentration in the rumen and reduced methane production in the rumen and rate of ketone oxidation. The LDL cholesterol concentration in plasma was significantly greater for cows fed monensin than for those fed no monensin, but there was no effect of monensin supplementation on plasma concentrations of triglycerides, total cholesterol, and HDL cholesterol.

\section{CONCLUSIONS}

In conclusion, flaxseed grinding and monensin supplementation at $0.02 \%$ of the DM had no effect on DMI of lactating cows. Grinding of flaxseed had no effect on $4 \%$ FCM yield and milk protein and lactose concentrations, and it decreased digestibility of $\mathrm{ADF}$ and increased that of CP and ether extract. Monensin had no effect on digestibility of the diet and milk production, but it decreased $4 \% \mathrm{FCM}$ yield as a result of a decrease in milk fat concentration. Feeding ground compared with WF increased concentrations of cis6-18:2, cis9, trans11-18:2, cis3-18:3 and decreased those of mediumchain and saturated FA in milk fat, which would improve milk FA profile from a human health perspective. Monensin supplementation increased concentrations of 
Table 5. Blood composition of Holstein cows fed whole flaxseed without monensin (WFCO), whole flaxseed with monensin (WFMO), ground flaxseed without monensin (GFCO), or ground flaxseed with monensin $(\mathrm{GFMO})^{1}$

\begin{tabular}{|c|c|c|c|c|c|c|c|c|}
\hline \multirow[b]{3}{*}{ Item } & \multirow{2}{*}{\multicolumn{4}{|c|}{ Treatment }} & \multirow[b]{3}{*}{$\mathrm{SE}$} & \multicolumn{3}{|c|}{$P$-value } \\
\hline & & & & & & & & Flaxseed \\
\hline & WFCO & WFMO & GFCO & GFMO & & Flaxseed & Monensin & $\times$ monensin \\
\hline Glucose, mg/100 mL & 53.6 & 67.1 & 62.4 & 64.9 & 4.4 & 0.47 & 0.09 & 0.23 \\
\hline Triglycerides, mg/100 mL & 12.5 & 15.0 & 13.3 & 15.4 & 1.4 & 0.70 & 0.13 & 0.90 \\
\hline Total cholesterol, mg/100 mL & 119.5 & 140.0 & 142.4 & 157.9 & 16.2 & 0.22 & 0.28 & 0.88 \\
\hline HDL cholesterol, mg/100 mL & 99.0 & 110.6 & 119.6 & 129.0 & 13.3 & 0.16 & 0.44 & 0.93 \\
\hline LDL cholesterol, mg/100 mL & 18.0 & 26.4 & 20.1 & 25.8 & 3.2 & 0.81 & 0.04 & 0.68 \\
\hline
\end{tabular}

${ }^{1}$ Least squares means with pooled SE.

cis9, trans 11-18:2 and decreased concentrations of saturated FA in milk fat, thus also improving milk FA profile for human health. Concentration of trans11-18:1 was higher and that of saturated FA tended to be lower in milk fat of cows fed GF with monensin than for those fed the other diets, thus suggesting that monensin supplementation was successful in decreasing ruminal biohydrogenation of FA of GF and increasing concentrations of beneficial FA in milk fat. Monensin supplementation and flaxseed processing are 2 useful dietary tools to modify milk FA profile.

\section{REFERENCES}

Abe, N., I. J. Lean, A. Rabiee, J. Porter, and C. Graham. 1994. Effects of sodium monensin on reproductive performance of dairy cattle. II. Effects on metabolites in plasma, resumption of ovarian cyclicity and oestrus in lactating cows. Aust. Vet. J. 71:277-282.

AOAC. 1990. Official Methods of Analysis. 15th ed. AOAC, Washington, DC.

Bell, J. A., J. M. Griinari, and J. J. Kennelly. 2006. Effect of safflower oil, flaxseed oil, monensin, and vitamin $\mathrm{E}$ on concentration of conjugated linoleic acid in bovine milk fat. J. Dairy Sci. 89:733-748.

Benchaar, B., H. V. Petit, R. Berthiaume, T. D. Whyte, and P. Y. Chouinard. 2006. Effects of dietary addition of essential oils and monensin premix on digestion, ruminal fermentation characteristics, milk production, and milk composition in dairy cows. J. Dairy Sci. 89:4352-4364

Chilliard, Y., A. Ferlay, R. M. Mansbridge, and M. Doreau. 2000. Ruminant milk fat plasticity: Nutritional control of saturated, polyunsaturated, trans and conjugated fatty acids. Ann. Zootech. 49:181-205.

Cochran, R. C., D. C. Adams, J. D. Wallace, and M. L. Galyean. 1986. Predicting digestibility of different diets with internal markers: Evaluation of four potential markers. J. Anim. Sci. 63:1476-1483.

DePeters, E. J., and J. P. Cant. 1992. Nutritional factors influencing the nitrogen composition of bovine milk: A review. J. Dairy Sci. 75:2043-2070

Dhiman, T. R., G. R. Anand, L. D. Satter, and M. W. Pariza. 1999. Conjugated linoleic acid content of milk fed different diets. J. Dairy Sci. 82:2146-2156.

Duffield, T. F., S. LeBlanc, R. Bagg, K. Leslie, J. Ten Hag, and P. Dick. 2003. Effect of a monensin controlled release capsule on metabolic parameters in transition dairy cows. J. Dairy Sci. 86:1171-1176

Duffield, T. F., D. Sandals, K. E. Leslie, K. Lissemore, B. W. McBride, J. H. Lumsden, P. Dick, and R. Bagg. 1998. Effect of prepartum administration of monensin in a controlled-release capsule on postpartum energy indicators in lactating dairy cows. J. Dairy Sci. 81:2354-2361.
Fellner, V., F. D. Sauer, and J. K. G. Kramer. 1997. Effect of nigericin, monensin, and tetronasin on biohydrogenation in continuous flow-though ruminal fermenters. J. Dairy Sci. 80:921-928.

Gonthier, C., A. F. Mustafa, R. Berthiaume, H. V. Petit, and D. R. Ouellet. 2004. Feeding micronized and extruded flaxseed to dairy cows: Effects on digestion and ruminal biohydrogenation of longchain fatty acids. Can. J. Anim. Sci. 84:705-711.

Gonthier, C., A. F. Mustafa, D. R. Ouellet, P. Y. Chouinard, R. Berthiaume, and H. V. Petit. 2005. Feeding micronized and extruded flaxseed to dairy cows: Effects on blood parameters and milk fatty acid composition. J. Dairy Sci. 88:748-756.

Goodridge, J., J. R. Ingalls, and G. H. Crow. 2001. Transfer of omega3 linolenic acid and linoleic acid to milk fat from flaxseed or Linola protected with formaldehyde. Can. J. Anim. Sci. 81:525-532.

Griinari, J. M., and D. E. Bauman. 1999. Biosynthesis of conjugated linoleic acid and its incorporation into meat and milk in ruminants. Pages 180 to 200 in Advances in Conjugated Linoleic Acid Research. Volume 1. M. P. Yurawecz, M. M. Mossaba, J. K. G. Kramer, M. W. Pariza, and G. J. Nelson, ed. AOCS Press, Champaign, IL.

Griinari, J. M., B. A. Corl, S. H. Lacy, P. Y. Chouinard, K. V. V. Nurmela, and D. E. Bauman. 2000. Conjugated linoleic acid is synthesized endogenously in lactating dairy cows by $\Delta 9$-desaturase. J. Nutr. 130:2285-2291.

Haimoud, D., M. Vernay, C. Bayourthe, and R. Moncoulon. 1995. Avoparcin and monensin effects on the digestion of nutrients in dairy cows fed a mixed diet. Can. J. Anim. Sci. 75:379-385.

ISO. 1978. Animal and vegetable fats and oils. Preparation of methyl esters of fatty acids. 1st ed. International Organization for Standardization, Geneva, Switzerland.

Kennelly, J. J. 1996. The fatty acid composition of milk fat as influenced by feeding oilseeds. Anim. Feed Sci. Technol. 60:137-152.

Kepler, C. R., and S. B. Tove. 1967. Biohydrogenation of unsaturated fatty acids. J. Biol. Chem. 242:5686-5692.

Khorasani, G. R., G. De Boer, P. H. Robinson, and J. J. Kennelly. 1992. Effect of canola fat on ruminal and total tract digestion, plasma hormones, and metabolites in lactating dairy cows. J. Dairy Sci. 75:492-501.

Lock, A. L., and P. C. Garnsworthy. 2002. Independent effects of dietary linoleic and linolenic fatty acids on the conjugated linoleic acid content of cows' milk. Anim. Sci. 74:163-176.

Marsh, W. H., B. Fingerhut, and H. Miller. 1965. Automated and manual direct methods for the determination of blood urea. Clin. Chem. 11:624-627.

Mohamed, O. E., L. D. Satter, R. R. Grummer, and F. R. Ehle. 1988. Influence of dietary cottonseed and soybean on milk production and composition. J. Dairy Sci. 71:2677-2688.

Murphy, J. J., J. F. Connolly, and G. P. McNeill. 1995. Effects on milk fat composition and cow performance of feeding concentrates containing full fat rapeseed and maize distillers grains on grasssilage based diets. Livest. Prod. Sci. 44:1-11.

Murphy, J. J., G. P. McNeill, J. F. Connelly, and P. A. Gleeson. 1990. Effect on cow performance and milk fat composition of including full fat soya beans and rape seeds in the concentrate mixture for lactating dairy cows. J. Dairy Res. 57:295-306. 
National Research Council. 2001. Nutrient Requirements of Dairy Cattle. 7th rev. ed. Natl. Acad. Press, Washington, DC.

Osborne, J. K., T. Mutsvangwa, O. Alzahal, T. F. Duffield, R. Bagg, P. Dick, G. Vessie, and B. W. McBride. 2004. Effects of monensin on ruminal forage degradability and total tract diet digestibility in lactating dairy cows during grain-induced subacute ruminal acidosis. J. Dairy Sci. 87:1840-1847.

Petit, H. V. 2002. Digestion, milk production, milk composition, and blood composition of dairy cows fed whole flaxseed. J. Dairy Sci. 85:1482-1490.

Petit, H. V., R. J. Dewhurst, N. D. Scollan, J. G. Proulx, M. Khalid, W. Haresign, H. Twagiramungu, and G. E. Mann. 2002. Milk production and composition, ovarian function, and prostaglandin secretion of dairy cows fed omega-3 fats. J. Dairy Sci. 85:889-899.

Petit, H. V., C. Germiquet, and D. LeBel. 2004. Effect of feeding whole unprocessed sunflower seeds and flaxseed on milk production, milk composition, and prostaglandin secretion in dairy cows. J. Dairy Sci. 87:3889-3898.

Phipps, R. H., J. I. Wilkinson, L. J. Jonker, M. Tarrant, A. K. Jones, and A. Hodge. 2000. Effect of monensin on milk production of Holstein-Friesian dairy cows. J. Dairy Sci. 83:2789-2794.

Plaizier, J. C., A. Martin, T. Duffield, R. Bagg, P. Dick, and B. W. McBride. 2000. Effect of a prepartum administration of monensin in a controlled-release capsule on apparent digestibilities and nitrogen utilization in transition dairy cows. J. Dairy Sci. 83:2918-2925.

Ruiz, R., G. L. Albrecht, L. O. Tedeschi, G. Jarvis, J. B. Russell, and D. G. Fox. 2001. Effect of monensin on the performance and nitrogen utilization of lactating dairy cows consuming fresh forage. J. Dairy Sci. 84:1717-1727.

SAS Institute. 2000. Release 8.02. 2000. SAS Inst. Inc., Cary, NC.
Sauer, F. D., V. Fellner, R. Kinsman, J. K. G. Kramer, H. A. Jackson, A. J. Lee, and S. Chen. 1998. Methane output and lactation response in Holstein cattle with monensin or unsaturated fat added to the diet. J. Anim. Sci. 76:906-914.

Scott, T. A., D. K. Combs, and R. R. Grummer. 1991. Effects of roasting, extrusion, and particle size on the feeding value of soybeans for dairy cows. J. Dairy Sci. 74:2555-2562.

Stern, M. D., G. A. Varga, J. H. Clark, J. L. Firkins, J. T. Huber, and D. L. Palmquist. 1994. Evaluation of chemical and physical properties of feeds that affect protein metabolism in the rumen. J. Dairy Sci. 77:2762-2786.

Tyrrell, H. F., and J. T. Reid. 1965. Prediction of the energy value of cow's milk. J. Dairy Sci. 48:1215-1223.

Van Der Werf, J. H. J., L. J. Jonker, and J. K. Oldenbroek. 1998. Effect of monensin on milk production by Holstein and Jersey cows. J. Dairy Sci. 81:427-433.

Van Nevel, C., and D. I. Demeyer. 1995. Lipolysis and biohydrogenation of soybean oil in the rumen in vitro: Inhibition by antimicrobials. J. Dairy Sci. 78:2797-2806.

Van Soest, P. J., J. B. Robertson, and B. A. Lewis. 1991. Methods for dietary fiber, neutral detergent fiber, and nonstarch polysaccharides in relation to animal nutrition. J. Dairy Sci. 74:35833597.

Voltolini, T. V., G. T. Santos, and M. A. Zambom. 2001. Influência dos estádios de lactação sobre a contagem de células somáticas do leite de vaca da raça holandesa e identificacão de patógenos causadores de mastite no rebanho. Acta Sci. 23:961-966.

Ward, A. T., K. M. Wittenberg, and R. Przybylski. 2002. Bovine milk fatty acid profiles produces by feeding diets containing solin, flax and canola. J. Dairy Sci. 85:1191-1196.

Wright, T., B. McBride, and B. Holub. 1998. Docosahexaenoic acidenriched milk. World Rev. Nutr. Diet. 83:160-165. 